\title{
Acknowledgments
}

Creating this anthology proved a pleasure because of the goodwill shown to the project by virtually everyone we approached. We would like to thank the authors of the texts and illustrations included in this work, or their heirs or other copyright holders, for authorizing reproduction of the material. Many authors wrote original pieces for this collection, or gave their time to rework previously published material: special thanks are due to Eulalia Bernard, Kirk Bowman, Marc Edelman, Steve Marquardt, Manrique Mata-Montero, Carmelo Mesa-Lago, Eugenia Rodríguez, and two writers who wish to remain anonymous. We are grateful to Paula Palmer, whose generosity with her time and materials was truly extraordinary given that we had never been in contact prior to undertaking this collection. Much of Steven Palmer's translation and thinking about this reader was done under the roof of Don Narciso, Nena, and Eylem Rodríguez, and Doña Blasa Barrantes, and he thanks them for that and so much more. The book would not have been possible without the cooperation of the Museo de Arte Costarricense, the Museo Nacional de Costa Rica, the Museo Histórico Cultural Juan Santamaría, the Archivo Nacional de Costa Rica, the University of Costa Rica newspaper Semanario Universidad, and the Centro de Investigación en Identidad y Cultura Latinoamericanas (CIICLA) of the University of Costa Rica. Our thanks also to Verónica Ríos, who helped make contact with some authors, and Ericka Lippi, who assisted with the collection of sources. At Duke University Press, we wish to extend our thanks to Miriam Angress for her editorial assistance, and especially to Valerie Millholland for encouraging us to pursue the project, providing excellent advice throughout, and keeping us going with her enthusiasm.

\section{A Note on Style and Sources}

Many of the selections in this anthology are abridged, and some have had footnotes and other scholarly armature removed. Readers interested in the full versions should refer to the Acknowledgment of Copyrights section.

The occasional term that may have an odd or pejorative ring for readers 
xiv Acknowledgments

(for example, the repeated use of the word Indian in selections on the colonial period) have been retained because they are the accepted norm in Latin American scholarship.

Translations in this anthology were done by Steven Palmer. 